\title{
Econophoria and the Power Constellation in East Asian Regionalism: Critical Leadership Questions
}

\author{
JAEWOO CHOO*
}

\begin{abstract}
East Asian regionalism is an on-going process, despite lacking much necessary "progress." A glimmer of hope from the rise of China is now being shed on the prospect of East Asian regionalism, thanks to states clustering economically to China in a process as economic "power constellation." Econophoria functions as a facilitator to the development process of East Asian regionalism. Given China's reluctance and regional aspirations in building necessary institutions and requisite leadership, however, this paper infers some possible forms of leadership that the US can develop regarding institutional bargaining. The US is perceived to be a critical player in finalizing East Asian regionalism for it is the only country that can render necessary leadership and therefore institutional building capability. If, as a regional player, the US wishes to recover its lost credibility and undermined trust, then the time is ripe for proper action. The article will briefly review the notion of power aggregation and power constellations so as to provide an analytical framework. It will then examine the prospect of an emerging regional order in the aftermath of China's power aggregation. In the following section, the article will assess the US position on the question of regional leadership and East Asian regionalism. The paper will conclude with possible strategic choices for the US in realizing regional aspirations.
\end{abstract}

Keywords: Econophoria, East Asian Regionalism, Power Constellation, Institution, Leadership

* Associate Professor, Kyung Hee University, Yongin, South Korea;

E-mail: jj33ch@kita.net

DOI: 10.16934/isr.17.1.201606.137 


\section{INTRODUCTION}

East Asian regionalism is an on-going process. It has been in process for almost two decades since the end of the Cold War but has yet to make any kind of substantive "progress" according to recent criticism (Jones and Smith 2007). East Asian regionalism is perceived to be in "process" because of the seemingly incessant efforts by the regional states with their attempts at economic integration. However, most of their goals seem far from actual realization. It remains to be seen whether or not the "spaghetti bowl" of free trade agreements at the bilateral level will lead to regional economic integration (Stubbs 2000; Dent 2003; Desker 2004). Regional cooperation in the financial sector seems to be moving in a more positive direction. The dividends of such cooperation have thus far been limited to no more than currency swaps. The institution of the "Asia Monetary Fund" (AMF) has been impeded by both internal and external setbacks. For some reason, economic integration or cooperation is taking more time for Asia than it did for Europe. If history is any indication of the future, economic integration seems to be a prerequisite for East Asian regionalism.

To the dismay of the regional affairs observers and experts, the region has yet to witness any kind of progress with regionalization. After having observed the process for the past two decades, many pundits are becoming skeptical of the possibilities. Nevertheless, there is a simmering light of hope with the rise of China. With the success of its economic development and modernization, China is becoming a force that cannot be ignored or neglected by the economies of the region. What was once described as growing interdependence between China and regional states during the first decade of the post-Cold War period is now undergoing a transformation. The dependency of regional states on China is real, and without China, it is now almost unimaginable for these states to achieve sustainable development in the new millennium. In other words, without much deliberation on China's part, regional states are clustering towards China; that is, the so-called "power constellation" is now at work in the region. This power dynamic has overtaken econophoria as a facilitator to the development process of East Asian regionalism. It also creates difficulties for finding a nexus between economics and security in the international relationship amongst the regional players. The difficulty in finding such a nexus has engendered challenges to the "Asian paradox."

Regional states are becoming more dependent on China to the extent that sustainable development is not conceived to be viable without healthy economic relations with China. Their perception is reaffirmed by the 2008 global financial crisis. Thanks to China's continuously healthy economic development, most regional states were able to overcome the crisis earlier than expected. South Korea, for instance, experienced fast recovery and had a breakout year with an economic growth rate of $4.6 \%$ in the following year. Many attributed their early recovery to 
the economic conditions in China. Hence, regional states can only be more grateful to the series of countermeasures and policies adopted in the wake of the financial crisis as they proved to be beneficial to China's own domestic economy and to the early recovery of the region's economies. As a result, regional states can be described as forming a power constellation around China, regardless of China's likes or dislikes.

If such a power constellation were to continue in the foreseeable future, it may endanger the prospect for East Asian regionalism. China has already done enough for the process. China has sufficiently embraced the extant rules, norms, and institutions in the region as a result of its proactive engagement with regional institutions since ending its isolation in 1978. China's prioritization of solutions for domestic socio-economic problems will preoccupy the attention of the Beijing leadership and perhaps undermine the availability of its sources for regional integration or regionalization. In addition, if the Chinese domestic market were to grow larger, to an extent that it will lessen the degree of external market dependency for sustainable development, then it may engender reservations on China's part regarding the regionalization process. In other words, China will not have to be deliberate with the push for regionalization. This is in part because the degree of dependency of the regional states on China is growing faster than vice-versa. As long as China does not pursue protectionism and continues to open its market to the regional economies, and these economies continue to enjoy greater dividends from the Chinese market than from the American market, then China will be highly appreciated by them as it is now.

For the sake of East Asian regionalism, it is time for the US to make a critical decision: whether or not it will assume the leadership required for the fruition of regionalization. ${ }^{1}$ With the inauguration of the Obama administration, the US announced a pivot to the region, and claimed to pursue multilateralism and cooperation as core means of its diplomacy (Nomination of Hillary R. Clinton to be Secretary of State 2010; Brooks 2009). To uphold such a commitment and to prove it to be effective and valid, the US is obligated to practice these diplomatic means. Whether such a commitment will be translated into greater leadership in regional affairs remains to be seen. The US already once lost its chance for this leadership, in the early 1990s, when China was not a factor. Its preoccupation with other world and regional affairs obviously led successive administrations to neglect the value of East Asian regionalism and its implications for the strategic interests of the US.

In other words, it is now the turn of the US to think seriously about assuming the necessary leadership role, on behalf of East Asian regionalism. It now has the opportunity to recover from past misdeeds and mistakes. This is particularly so because China, as proclaimed by itself, will not lead at all. The concern is that the regional states seem to be at a loss with China's proclamation, despite their long 
aspiration for regionalism and their desire for China's leadership. If the US were to recover its lost credibility and undermined trust in the region, then the time is ripe for action. The East Asian regionalism or regionalization process has not been successful because of a lack of leadership (Tang 2005). Such leadership cannot be fulfilled by the amendment of bilateral relationship between China and Japan (Fan 2008). This is in part because Japan's dependency on China is also growing at a rapid pace (Wang 2009), and this was evident in the shift of the Hatomoto government's policy towards China in particular and East Asia in general.

Thus, for the US not to repeatedly make the same mistakes with respect to East Asian regionalism, this paper advocates that the US pursue directional leadership. In addition, in the process of bargaining for institution-building or institutionalization for East Asian regionalism, it also suggests considering structural leadership instead of entrepreneurial or intellectual leadership. ${ }^{2}$ The motivations for such an argument are twofold. One is China's unwillingness to assume any kind of leadership, if and only when we can treat China's statement as truth. The other lies in the fact that the US is a stakeholder in the region. Thus, the US will not assume leadership for intangible values (i.e. entrepreneur leadership), nor will it rely on the efforts by individual figures for such fruition (i.e. intellectual leadership), as this will be a deliberative or reflective process.

Given that China's reluctance and regional aspirations are both evident, this paper would like to infer some possible forms of leadership that the US can develop regarding institutional bargaining (Beeson 2009). Assuming that there are shared ideas and identities among regional states, which are prerequisites to the fruition of regionalism, there is only one shortfall to the full realization of regionalism: institutions (Lake 2001; Koremenos, Lipson and Snidal 2001; Anreani 2000). Institutions will be facilitated through institution bargaining. Hence, the US will have to assume a critical leadership to facilitate such a process (Beeson 2003). The following section will therefore briefly review the notion of power aggregation and power constellations so as to provide an analytical framework. It will then examine the prospect of an emerging regional order in the aftermath of China's power aggregation. In the following section, the article will assess the US position on the question of regional leadership and explore why America has withheld from assuming any kind of leadership role for East Asian regionalism. The paper will conclude with some remarks on the possible strategic choice for the US in realizing the regional aspiration for regionalism. To substantiate the thesis of the article, it will explain why regionalism is only meaningless to China in the context of its preferred strategic choices.

\section{REGIONAL ORDER VIA A POWER CONSTELLATION}

The success of economic reforms over the past thirty years enabled China to 
aggregate much power. The growth in its hard power has been visible for many years and is noticeable in many areas, including military and economic. China's soft power has yet to grow to match the scale and strength of its hard power. However, Chinese soft power is rapidly meeting all the prerequisites through the development of ideational means, e.g. ideas, identities, institutions, in various channels of communication. Despite the visible imbalance in the growth of soft and hard power, a power aggregated China (with both soft and hard power) represents a dynamic force in East Asia. China will be a force strong enough to have an impact on the consequences of regional order development and therefore on structural development in particular. This will entail changes in the power configuration and subsequently in the very foundation of the region's international order. In such a case, a serious question arises: How will a power aggregated China use its power? Will it be assertive in the developmental discourse of a future regional order? Will it be aggressive in pursuit of an order that suits and appropriates its interests?

Traditionally and historically, previous East Asian orders evolved around a strong powerful regional state, i.e. a power constellation (Pedersen 2002). Regional states would cluster around the strong and powerful state for a variety of reasons. For most of East Asian history its order was founded on the tribute system, which formed a constellation of the neighboring states around the powerful state. Some constellated for their own interests and others were attracted by the benevolence of the powerful state. Hence, the traditional Asian way of international order does not impose or coerce others to join any form of structural union, but rather attracts others to be part of the union with appeals from both hard power and soft power. From this perspective, power aggregation and ensuing constellations emerge through the diffusion of ideas, or ideational process, exemplified by the merit of the powerful (Jones and Smith 2007).

This process is consolidated with the commitment of the powerful as demonstrated in its benevolent and benign conduct. Chinese civilization was not imposed but was rather adopted and pursued by surrounding nations. International order centered on China, or the Chinese tribute system, and was in large part maintained by Chinese benevolence. When China became violent and belligerent, the power aggregation would disperse in all directions, sometimes resulting in a balancing or hedging against China. In today's world of East Asia, it is seemingly a case of déjà vu. Obviously, there is a clustering of regional states around China, and its power aggregation is increasingly hard to deny. Norms and institutions are being shaped in a rather traditional way, where values of benevolence and merit appear in the western view as trust, confidence, and respect (Kang 2003).

In today's world, the power constellation around China is visible once again. The constellation by regional states is a result of their changing perceptions to- 
wards China. The opening of China in 1978 meant the opening of contacts and exchanges with neighboring states. It gave these states and China an opportunity to enhance their mutual understanding and lower their suspicions of communist China in relation to their national security. After years of persistent countering efforts against the so-called "China threat" theory through the practice of "peaceful rise" diplomacy, China was able to sow the seeds of confidence and trust in its neighbors. This diplomatic practice included rigorous efforts in conceptualizing, if not theorizing, "peaceful rise" and later "peaceful development." This diplomacy also encompassed various confidence-building measures with China's proactive participation in multilateral security engagement and initiatives in the signing of successive peace-related regional treaties that it was once reluctant to sign. Simultaneously, neighboring states became more comfortable dealing with China in diplomatic terms and began to realize the value of China as a land of opportunity. They would soon recognize that the degree of their dependency on China was beyond their expectations. Furthermore, for these states China represented a dilemma in terms of their relations with the US.

The neighboring states of China did indeed encounter anew security dilemma. Over the years, China proved to be sincere in its pursuit of multilateralism and international cooperation in the security realm. It has been, for instance, a strong advocate for the institutionalization of the ongoing Six-party talks (Choo 2005). Its rigorous pursuit of this multilateral approach also improved China's image as a responsible state and apparently convinced enough regional states of the validity of China's peaceful rise theory.

China has enhanced regionalization in a variety of areas, ranging from economic (e.g. APEC, ASEAN+3, ASEAN+1) to financial (e.g. Chiang Mai Initiative), and political (e.g. the Shanghai Cooperation Organization, or SCO), the East Asia Summit (EAS), to security (e.g. the Treaty of Amity and Co-operation, or TAC), and the Six-party talks (SPT). China has almost fully embraced regionalnorms, rules, and institutions, also making substantial contributions to the creation of new institutions. In the process of the institutionalization of newly founded multilateral forums, China has also displayed critical leadership in institutional bargaining against other regional states (Chung 2008). The outcomes are twofold. While China has successfully garnered much respect from other regional peers for its own respect for regional norms and institutions via active engagement, it has also served its national strategic interests by founding new ones in the region (Ren 2009).

A critical element that could significantly determine the outcome of the power constellation process surrounding China comes from the rival to China's rise, the extant hegemon in the region. Power constellation theory presupposes that the regional hegemon, in this case the US, will sooner or later have to make a significant structural adjustment to the changing power configuration and ensuing ideational 
changes in the perception of other regional states as a result of a rising power such as China. Power aggregation and the ensuing external constellation are all in favor of China, if the current practice of China's foreign policy in power sharing commitment continues to prevail in the foreseeable future. On the contrary, the US still favors a reliance on the hub and spokes structure of its alliance system in preserving and securing its strategic interests in the region. The US strives to bind the individual ally on the basis of mutual commitment and reciprocal principle, but it remains to be seen whether or not American efforts can prevail against the inertia of the power constellation.

\section{THE QUESTION OF US LEADERSHIP}

Given that the regionalization of the security process will continue in the foreseeable future, coupled with the changing landscape in the regional international relations, the US is at a crossroads (Pempel 2008). The US must seriously consider making a positive contribution to such a cause as long as it wants to identify itself with, or sustain its preeminence in, East Asia. ${ }^{3}$ According to neoliberalism and constructivism, the leadership factor is critical to taking the multilateral security arrangement in the region to the next level. Hence, a critical set of questions arises: How and to what extent does America's hegemony contribute to this process? Conversely, US absence and/or unwillingness can hamper the process. Such a debate arises because leadership that can guide the process to actual fruition is in demand. In addition, it will greatly help the region capitalize the process to better serve the interests of the US as well as the region's. However, the US does not seem to be too interested in this process for its own reasons. ${ }^{4}$

The US has strong reservations regarding full participation because of arguments including rational choice, cost-effect analyses, and others. The US has thus far regarded the region as strategically valuable to its global interests, but yet as relatively less valuable than Europe, where it displays a more robust commitment to multilateralism and institutions. Hence, while the US extends a great deal of rhetorical support for the ideas of Asian multilateralism and institution-building, it has yet to act accordingly (Reisman 1999-2000). The American policy adheres to bilateralism. Bilateralism is the foundation for the strategic structure it considers appropriate for serving its security interests. Multilateralism is a well-known supplement to the bilateral security alliance system. Multilateralism is for rhetoric and bilateralism is for practice.

The US strategic stance on multilateralism in relation to its regional interests is well known (Goh 2004; Ikenberry 2004, 358). This is a great supplement to its bilateral alliance, because it can help confirm its commitment by mere rhetoric. In a way, this rhetoric also contributes to the illusion, among western scholars, of view the regionalization process as lacking substance (Beeson 2004). Rhetoric 
does not entail any cost. It does, however, help put the US at an advantageous end with respect to the calculation of cost and effect relations with the American public and Congress. By delinking the causal relations between the need and necessity of such a regional security arrangement, the US helps itself with rational choice theory. The need is there; however, there is a margin between possible gains of interest and possible losses. In terms of obligations, expenses, responsibilities and freedom. Rhetoric does not require any further reduction in its policy choices and policy autonomy (Mastanduno 2005, 321-24).

However, as believed by many observers and pundits, the underlying implications of the rise of China, a revived Russia, and growing animosities with Japan, together with changing nature of security, are all concerning for US regional interests. Given the sustainability of China's peaceful rise, China's power aggregation will have a profound structural effect on the region's balance of power. Its willingness for power sharing is also another source of concern as this will signal Beijing's greater commitment to regionalization and institution-building. All these put together could shift the weight in favor of China as opposed to the US.

The US seeks to perpetuate the US-Japan military alliance as the cornerstone of its structural strategy. However, its explicit and tacit support for the cause of greater flexibility and more effective deployment capacity of Japanese forces will cause regional states to doubt America's intentions, notwithstanding its commitment to regional peace and stability. American military presence in the form of an alliance with Japan has successfully maintained Japan as a pacifist state. Nonetheless, given the growing recognition of America as the maestro behind the Japanese military reforms, regional states will be compelled to doubt the original intent of the alliance system. In addition, a revived Russia will not assist the US in any more positive ways in sustaining its predominant posture in the region. Russia, for instance, will become the most wooed country in the region because of its natural resources in which all regional states are interested.

However, notwithstanding the absence of substance, the regional security process will continue whether the US is involved or not. The general mood in the region has changed since the Asian financial crisis in 1997, and it is evident in the original intent in formalizing East Asian Summit (EAS) when regional states, led by China and Malaysia, wanted to exclude the United States. Although it is difficult to predict if the process will ever be finalized with substance, it is certain that it will continue. For the US to maintain its primacy in the region, it should act with concrete measures and stay away from so-called "pragmatism." ${ }^{5}$ Unilateralism does not work effectively in the region, where American leadership is highly appreciated, being based on such universal values as human rights, democracy, and freedom.

Unilateralism will not, and cannot, sustain itself in the age of information technology and globalization. ${ }^{6}$ A technological world cannot accommodate the 
interests of unilateralism. The world is more conscious of the intentions and purposes of American unilateralism. It has become smarter with its understanding of American foreign policy. In the end, this only helps undermine the efficacy of American soft power (Nye 2004).

The diplomatic efficacy of soft power may be difficult to judge because of the subjectivity on part of the evaluators, and when it backfires, the consequences are obvious. Ill-perceived soft power will easily undermine its own merits and tarnish the intended projection of an image. The effect generated by such illperception will significantly undermine the trust and confidence that others have in the actor with soft power. The US is not an exception to this in the recent past. Moreover, the impact has extended to give rise to serious challenges to US public diplomacy (Scalapino 2004, 369). These challenges are witnessed by various negative perceptions and related actions against the US. A rising number of antiAmerican protests, growing anti-American sentiment, and more importantly, ensuing anti-American attitudes exemplify the serious nature of challenges confronting America's public diplomacy. Moreover, America's adherence to unilateralism, its contempt of multilateralism, and its perception of institutions as "instruments of convenience" (Mastanduno 2005, 317) will significantly undermine its position to an extent that it might lose its place in the regional process if it continues to only deploy rhetoric.

In its efforts to preserve hegemony especially in East Asia with the concept of Asia-Pacific waning (Beeson 2006), the US aims to abide by the trilateral relationship with Japan and South Korea. The two-versus-one triadic dividing strategy of the Cold War cannot balance the prospective structural change with China's increasing power aggregation capacity both in political and economic terms. The US also has to adjust to a new trend appearing in the landscape of East Asian international relations since 911, that is, "competitive coexistence." "Strategic trust" has been burgeoning in East Asia since 1997 when it realized the urgency of fostering regionalism and regional cooperation. It was reinforced by the wake of the 911 as well as by the second nuclear crisis of North Korea in 2002. The regional dimension in foreign policies of regional states now takes the region "as a means of taking action as part of a more comprehensive set of strategies within a framework of (this) growing 'strategic trust" (Haake 2002, 27; Gilson 2007, 151). A strategy of balancing could be imposed on the US in the foreseeable future. This could come from such challenges as the need to balance the regional threats ("balance of threat") (Mastanduno, 1997). In such a case, "cooperative hegemony" could be a key answer to the question of how far and to what extent the US should involve itself in the regional security process (Pedersen 2002). Hence, a new paradigm needs to be developed that can balance America's preference for bilateralism within the context of multilateralism (Harris 2001). 


\section{CHINA'S APPROACH TO REGIONALISM}

The opening of China in 1978 meant the initiation of contacts and exchanges with neighboring states. It gave these states and China an opportunity to enhance their mutual understanding and undermine their suspicions of communist China in relation to their national security. Through this opportunity, China was able to aggregate hard power with successful reforms in its economic institutions and laws. Through the process of opening up and reforms, China could understand the world much better, whilst continuing to accrue material gains. After twenty years of economic success, China was confronted with an opportunity to show the world what it had learned through the socialization process during its economic engagement. Chinese endeavors related to key decisions during the 1997 Asian financial crisis proved the results of its social learning. Ever since then, coupled with growing confidence in multilateral diplomacy and regional engagement, China began to proactively pursue multilateral and/or cooperative diplomacy at the regional level. Successive results in APEC, ASEAN+3, ARF, SCO, ASEAN+1, the Four-party talks, and the Six-party talks all reveal China's growing intellectual capacity regarding regional norms and rules, as well as the mechanisms and processes by which multilateral institutions work. A series of engagement activities by China exemplifies the consequences of such social learning process on China's part. Hence, it seems that socialization is at work effectively for China as it becomes more accommodating to international rules and institutions (Harris 2001).

If China continues its social learning efforts and becomes more integrated into the world system, the Chinese idea of power will become much easier to perceive and hence predict. Moreover, the rise in transparency regarding the Chinese idea of power will undermine the chances for misperception or misunderstanding by others who might otherwise fear China's rise. After all, power does not determine ideas, and the outcome of power will depend on ideas. If this were to happen as a result of social learning, for instance, then power transitions among states will not inevitably lead to conflict (Legro 2007, 3). Conversely, ideas determine power. They manipulate the destiny of power. They can exploit it in accordance to the nature of an idea. If the idea is to harm others, then power will be violent and cruel. If it is for a benign purpose, then power can advance good. Ideas can control the nature and character of power.

Hence, a rising power does not always necessarily seek conflict with others, especially if it does not deem power an absolute means for achieving national interests. Conflict will become unavoidable if states decide to materialize selfinterest in a coercive and/or unilateral fashion. States usually have two choices for using power. One is with the benign intention to accommodate the prevailing institutions, norms, rules, and structures of the status quo. This is supplemented by the desire for peaceful world that fits the purpose of development and prosperity. 
The other choice is for power to challenge the status quo by manipulating the notion of "self-help" in a world of anarchy. Given the world's anarchic nature, this option can easily be exploited by powerful states pursuing self-interested, selfcentered, and self-fulfilling behavior. When these orientations are implemented unilaterally, the status quo will be devastated. In either case, states must decide on the uses of power when the expansion of their power demands more space and resources.

Power can become a useful and effective tool. And states can be subjective and judgmental about the capacity of their own power as well as those of others. Regardless, when states are in the midst of power transition, with their destination uncertain in the eyes of others, states will be judged. This is simply the nature of the state. And so is their desire to expand their interests. The expansion of interests does not necessarily mean revoking the status quo; it might mean preserving its own boundary of influence against checks from the extant powers. Hence, regardless if a state desires to change or preserve the status quo, some prerequisites must be observed and fulfilled for either end. The state must have the capacity to do so, either independently or by relying on others for help. If a state perceives itself to be strong enough to challenge the existing hegemonic power, the two states are bound for conflict unless there is a compromise.

If the state cannot independently challenge the powerful, it will have to seek external help. In this case, the state and its helper must possess shared interests to form any kind of coalition, or even alliance, to go against the powerful. Here the interests are simple: whether or not they will benefit. Once they are able to find shared interests, there has to be a certain degree of trust and confidence between the two parties before committing to the pursuit of these interests. If the trust and confidence are absent, their commitment will be questionable, fragile, and untrustworthy. Under these circumstances, the state with desire to preserve or change the status quo will have to take the initiative to seek ways for confidence-building measures and processes, especially if it lacks the power to act independently.

Changing or preserving the status quo requires a great degree of perseverance on the part of the rising power. It will be constantly checked by the extant hegemon. Neighboring states will be a critical variable to the cause of either effort by the rising power. They are critical as a source of hedging strategy against the powerful or a source of alliance for the balance of power. Should the confidence-building process be deemed necessary, then inter-state relations are likely to be devoid of conflict and war, in part because coercion is usually out of the question. This is perhaps where China stands in relations with the neighboring states. Nevertheless, once the process is completed with the inception of a new powerful actor, whether it has the backing from a group of states or an individual state in an alliance, it will be perceived to be ready to exert its power with respect to the status quo. At this juncture, a critical moment arises for the ideas of nation. 
In a unipolar world, China is simply overmatched by the powerful (i.e. U.S.), and neither is it ready to challenge the status quo. China has yet to make an explicit move for a coalition with the purpose of going against the US. Instead, it prefers to preserve the status quo. The Chinese preference has been substantiated by the emphasis on the exercise of restraints on action (tiaoguang yanghui), constraints of choices (yousuo zuowei), and responsibility in implementation (fu ziren) in its external relations. ${ }^{7}$ Such a prudent way of exercising power gives rise to China's dual identity. The first identity discards China's ability to influence the outcome of international affairs because of its status as a developing country. The second identity, however, asserts it as a pole in the sense that it can exert a certain degree of influence, in a collective way, on the outcomes of political, diplomatic, and partially military developments in the world affairs. Given China's dual identity, building a premise for the understanding of its ideas of power is extraordinarily difficult, if not impossible. At this particular stage, we can infer, based on the words of the Chinese leadership, that China's idea of power is to preserve the status quo, and that its paradigm should be understood in the structural balance of the context of power.

It would be a cliché to the realists who believe the paradigm would lose ground after China completes its ascendancy to a great power status. China will eye hegemony because of the nature of state (Gries 2005). Yet, we are not willing to deny our propensity in our attempt to understand China's predicament. China needs peace and stability to prevail at least for the foreseeable future. Because of China's deep integration into the world economic and political system, coupled with its growing influence on the world economy, if not yet politics, an economic depression in China, for instance, would easily translate into that of the world and vice versa. Thus, how China will shape its ideas of power will be critical to the well-being of the world. The ideas of nations will consequently influence how China will conceive its rising power and changing status. Therefore, these ideas even influence the fate of the world. ${ }^{8}$

However, there exists a dark side to China's commitment to the idea of benevolent and responsible use of power. Although it is strongly endorsed by the Chinese Communist Party (CCP), the leadership of the CCP has not totally abandoned its ultimate foreign policy goal: a new multipolar world with its well-deserved position as one of the major poles. China has in recent times exercised a great deal of restraint in going public about this goal because it fears it could give credence to the theory of China as a threat. China also fears the consequences of the negative impact that the prevalence of realism may have on China's pursuit of economic modernization. Hence, China has successfully shown great restraint in calling for the ultimate goal in its recent official policy documents. Whether or not this restraint is temporary is not known. It is safe to presume that at least for the foreseeable future, the central theme behind China's national idea of power is to 
accommodate the current status of world peace and order, which is deemed to be conducive to China's own peaceful development (Hughes 2005, 123-124).

\section{CONCLUSION}

China has aggregated much power from the success of its economic reforms and open door policy. Such success has facilitated China's rise, and the rise of China will be further propelled by the growth of its soft power. The consequences of China's power development began to show in the form of the regional power constellation. Neighboring states are becoming more dependent on China at least in economic terms. However, growing economic dependence is generating a spillover effect into other realms including security. Furthermore, the growing dependency of the regional states on China is naturally leading to their constellation around China. In this process, regional states confront a serious challenge, or rather a dilemma, with respect to their relations with the US. The time has arrived for these regional states to (re)think their strategic and national interests when searching for a solution to such a dilemma. The reality, however, is that the current direction of development in China's foreign policy seems more fitting to the interests of these regional states.

The US still holds many reservations about multilateralism and the regionalization process. East Asia is not exception in this case. The US still prefers to rely on bilateral relationships to preserve the current regional order. From this perspective, it is safe to argue that US foreign policy towards the region is opposite to the ongoing trend in the international system, and opposite to the region's aspiration for regionalism based on multilateralism and cooperation. On the contrary, China's recent foreign endeavors have been in accord with such regional aspiration. With spare hard power readily available and soft power growing, China has the ability to appeal to this regional aspiration. Regardless of its motivation, China's adherence to the principle of multilateral cooperation, as a solution to international conflict, will attract more regional states and facilitate the power constellation process.

However, China will not become the leader in the region, as emphasized by its government over the past decades since its opening. With power constellations favoring China, its government may not consider it necessary to pursue further regionalism that may require new institutions. In other words, China is basically satisfied with the degree of its engagement and integration in the regionalization processes currently underway. This is in part because these processes are already serving the ultimate goal of Chinese foreign policy, i.e. peace and stability in the neighboring environment. In other words, the status quo is further reinstated by the enhancement of extant institutions and newly created ones. It is also in part because China has gained intangible value from active participation in these processes, i.e. improvement in its national image and the projection of its image as 
a responsible state.

Under these circumstances, East Asian regionalism may well stall due to a lack of leadership. If China were satisfied with the way regionalism has proceeded in the form of the so-called "Asian way," coupled with America's preference for bilateral cooperation, the prospect for East Asian regionalism is not too sanguine. For East Asian regionalism to achieve the degree of integration of Europe, the region has to expect greater leadership from either China or the US. However, neither is willing to assume this leadership.

It is perhaps time for the US to take the initiative at this critical juncture. The US has already lost its chance once in the early 1990s. The US also lagged behind China in the regionalization processes, undermining its credibility and trust. If the US were sincere about its call for multilateralism and cooperation with regional states, as claims the Obama administration, it can lead the region with the socalled "directional leadership" in collaboration with China. In the institutionalization process of regionalism, the US could assume structural leadership, if it truly wanted to promote multilateralism and cooperation as the core means of its diplomacy. No other forms of leadership such as entrepreneurial or intellectual leadership would serve American interests in the region. American interests are too overwhelming to assume entrepreneurial leadership; also, there is not enough time for it to assume intellectual leadership. Hence, the time might be ripe for the US to assume structural leadership in the regionalization process. If the US loses this opportunity, and China continues to transform itself into a regional power as predicted by many by year 2020 or 2025 , then the US may waste another decade, as it did in the 1990s.

\section{REFERENCES}

Anreani, Gilles. 2000. "Why Institutions Matter.” Survival 42(2): 81-95.

Beeson, Mark. "Does Hegemony Still matter? Revisiting Regime Formation in the Asia-Pacific.” A Paper Presented at a Conference on Globalization and Economic Security in East Asia: Governance and Institutions, Singapore. September 2003.

Beeson, Mark. 2004. "Multilateralism, American Power and East Asian Regionalism.” Working Paper Series. No 64, May. City University of Hong Kong, accessed April 23, 2007, http://espace.library.uq.edu.au/view/UQ:10475/mb_ hk_mlat_04.pdf.

Beeson, Mark. 2006. "American Hegemony and Regionalism: The Rise of East Asia and the End of the Asia-Pacific." Geopolitics 11(4): 541-560.

Beeson, Mark. 2009. "Hegemonic Transition in East Asia? The Dynamics of Chinese and American Power." Review of International Studies 35(1): 95-112.

Brooks, Michelle Austein. 2009. "Hillary Clinton Seeks to Renew U.S. Leadership 
Through Diplomacy." Embassy of the United States in Korea, January 13, accessed, http://seoul.usembassy.gov/utils/eprintpage.html Accessed on January 19, 2009.

Brooks, Stephen G. and William, C. Wohlforth. 2005. "International Relations Theory and the Case against Unilateralism." Perspectives on Politics 3(3): 509-524.

Choo, Jaewoo. 2005. "Is Institutionalization of the Six-party Talks Possible?" East Asia: An International Quarterly 22(4): 39-58.

Chung, Chien-Peng. 2008. "China's Approaches to the Institutionalization of Regional Multilateralism." Journal of Contemporary China 17(57): 747-764.

Fan, Yongming. 2008. "Searching for Common Interests between China and Japan: A Chinese View." Journal of Contemporary China 17(55): 375-382.

Gilson, Julie. 2007. "Strategic Regionalism in East Asia." Review of International Studies 33: 145-63.

Goh, Evelyn. 2004. "The ASEAN Regional Forum in United States East Asian Strategy." The Pacific Review 17(1): 47-69.

Goh, Evelyn. 2007/08. "Great Powers and Hierarchical Order in Southeast Asia: Analyzing Regional Security Strategies." International Security 32(3): 113157.

Gries, Peter Hays. 2005. "China Eyes the Hegemon." Orbis: 401-412.

Haacke, Jurgen. 2002. "Seeking Influence: China's Diplomacy toward ASEAN after the Asian crisis." Asian Perspective 26: 13-52.

Harris, Stuart. 2001. "China and the Pursuit of State Interests in a Globalizing World." Pacific Review 13(1): 15-29.

Hemmer, Christopher and Peter J. Katzenstein. 2002. "Why there is No NATO in Asia? Collective Identity, Regionalism, and the Origins of Multilateralism." International Organization 56(3): 575-607.

Hughes, Christopher R. 2005. "Nationalism and Multilateralism in Chinese Foreign Policy." The Pacific Review 18(1): 119-135.

Ikenberry, John G. 2004. "American Hegemony and East Asian Order." Australian Journal of International Affairs 58(3): 353-367.

Jentleson, Bruce W. 2007. “America's Global Role after Bush.” Survival 49(3): 179200.

Jones, David Martin and Michael L. R. Smith. 2007. "Constructing Communities: The Curious Case of East Asian Regionalism.” Review of International Studies 33: $165-186$.

Kang, David. 2003. "Getting Asia Wrong: The Need for Analytical Framework." International Security 27(4): 57-85.

Koremenos, Barbara, Charles Lipson, and Duncan Snidal. 2001. "The Rational Design of International Institutions." International Organization 55(4): 761799.

Lake, David A. 2001. "Beyond Anarchy: The Importance of Security Institutions." 
International Security 26(1): 129-160.

Legro, Jeffrey W. 2007. Rethinking the World: Great Power Strategies and International Order. Ithaca: Cornell University Press.

Mastanduno, Michael. 2005. "US Foreign Policy and the Pragmatic Use of International Institutions." Australian Journal of International Affairs 59(3): 317-33.

Nomination of Hillary R. Clinton to be Secretary of State, Hearing before the Committee of U.S. Foreign Relations United States Senate One Hundred Eleventh Congress, First Session, January 13, 2009. Washington, D.C: U.S. Government Printing Office, 2010, accessed March 2, 2011, https://www.gpo. gov/fdsys/pkg/CHRG-111shrg54615/pdf/CHRG-111shrg54615.pdf.

Nye, Joseph S. 2004. Soft Power: The Means to Success in World Politics. NY: Pacific Affairs.

Pedersen, Thomas. 2002. "Cooperative Hegemony: Power, Ideas and Institutions in Regional Integration.” Review of International Studies 8: 677-96.

Pempel. T. J. 2008. "How Bush Bungled Asia: Militarism, Economic Indifference and Unilateralism Have Weakened the United States Across Asia." The Pacific Review 21(5): 547-581.

Qian, Jichen. 2003. Waijiao Shiji (The Stories of Diplomat Qian Jichen). Beijing: Shijie zhishi chubanshe.

Reisman, Michael W. 1999-2000. "The United States and International Institutions." Survival 41(4): 62-80.

Ren, Xiao. 2009. "Between Adapting and Shaping: China's role in Asian Regional Cooperation." Journal of Contemporary China 18(59): 303-320.

Rozman, Gilbert. 1999. "China’s Quest for Great Power Identity.” Orbis: 383-402. Scalapino, Robert A. 2004. "Asia-Pacific Security-the Current Balance of Power." Australian Journal of International Affairs 58(3): 368-76.

Tang, Shiping. 2005. "Leadership in Institution Building: The Case of ASEAN+3." In Regional Integration in East Asia and Europe: Convergence or Divergence? Edited by Bertrand Fort and Douglas Webber. London and New York: Routledge.

Tang, Shiping and Peter Hays Gries. 2002. “China’s Security Strategy: From Offensive to Defensive Realism and Beyond." EAI Working Paper. No.97. Singapore: East Asian Institute, National University of Singapore.

Wang, Qian. 2009. Riben yao zhimian zhongguo shijie (Japan wants to face the China century) (The original work was by Huitian Hongjuan). Hatoyama (fushan) zhengzai xiezuo youguan guojia de zongchou lish he hengchou xianzai de dazuo (Hashimoto is now writing a grand piece on a nation's vertical (history) and horizontal (present) axis). Dongfang zaobao: Book review, September 20 .

Young, Oran R. 1991. "Political Leadership and Regime Formation: On the Development of Institutions in International Society." International Organization 45(3): 281-308. 


\section{ENDNOTES}

1 Such a question was already raised and analyzed by Hemmer and Katzenstein (2002). But the authors do not sufficiently offer the answers on the absence of will on the part of the US with respect to East Asian regionalism.

2 Young (1991) claims that structural leaders are experts in translating the possession of material resources into bargaining leverage cast in terms appropriate to the issues at stake in specific instances of institutional bargaining (p. 288). Thus, the essential feature of structural leadership lies in the ability to translate structural power into bargaining leverage as a means of reaching agreement on the terms of constitutional contracts in social settings of the sort exemplified by international society. Entrepreneurial leaders rely on negotiating skill to frame issues in ways that foster integrative bargaining and put together deals that would otherwise elude participants endeavoring to form international regimes through institutional bargaining (p. 293) Entrepreneur leaders function as (1) agenda setters shaping the form in which the issues are presented for consideration at the international level; (2) popularizers drawing attention to the importance of the issues at stake; (3) investors devising innovative policy options to overcome bargaining impediments; and (4) brokers making deals and lining up support for salient options. They are not third parties unlike mediators. They work to frame the issues at stake instead of limiting themselves to efforts to assist or facilitate negotiations among the principals. They are individuals and not states. Intangible values refer to something like the achievement of a peaceful world, whereas tangible values concern the maximization of monetary rewards (p. 296). Intellectual leaders include an individual who produces intellectual capital or generative systems of thought that shape the perspectives of those who participate in institutional bargaining and, in so doing, play an important role in determining the success or failure of efforts to reach agreement on the terms of constitutional contracts in international society. Such leaders tend to rely on the power of ideas to shape the intellectual capital available to those engaged in institutional bargaining (p. 300). Whereas an entrepreneur leader is an agenda setter and popularizer who uses negotiating skills to devise attractive formulas and to broker interests, however, the intellectual leader is a thinker who seeks to articulate the systems of thought that provide the substratum underlying the proximate activities involved in institutional bargaining (p. 300).

3 A realist like Mastanduno $(2005,318)$, however, denies that this notion of America is at a crossroads because it is politically important, but analytically misleading, in that both "sides presuppose multilateralism as the baseline from which the US approach to international institutions should be judged."

4 Jentleson $(2007,182)$ once argued the Bush administration has "remained disengaged at best, obstructionist at worst."

5 The notion of pragmatism is basically "you do it at your own discretion, own convenience, and use whatever as an instrument of convenience for your own interest" (Mastanduno 2005, 329-31).

6 The possible costs of US unilateralism will "(1) spurt the formation of a coalition to check US power; (2) reduce efficiency gains through lost opportunities for institutionalized cooperation; (3) undermine the legitimacy of the American-led international order" (Brooks and Wohlforth 2005, 510).

7 The meaning of "Tiaoguang yanghui" was articulated by Deng Xiaoping to Chinese public through his Selected Works of Deng Xiaoping (Beijing: People's Daily), Vol. 3, p. 321. For a detailed analysis of its definition, please refer to Tang and Gries (2002: 6) and especially footnote No. 23.

8 Beginning in the late 1990 s, some explain that China began to identify itself as a great power (Rozman 1999). 